\title{
Determination of The Oxide Mineral Contents of the Tegal Lenga Beach Iron Sand by Using XRD
}

\author{
P. Suardana ${ }^{1 *}$ I B. Sujana. $\mathrm{M}^{2}$, Nyoman Wendri ${ }^{3}$ \\ ${ }^{1,2,3}$ Department of Physics, Faculty of Mathematic and Natural Sciences, Udayana University \\ Kampus Bukit Jimbaran, Badung, Bali, Indonesia (80361) \\ *suardanaputu@unud.ac.id, sujana_manuaba@unud.ac.id, wendri@unud.ac.id
}

\begin{abstract}
The research of determination of the oxide mineral contents of the Tegal Lenga Beach iron sand by using XRD has been done. Iron sand samples were taken from the top layer of the Tegal Lenga Beach sand. The three sand samples were taken from three different places which were separated at a distance of $15 \mathrm{~m}$ one another. The separation process is carried out using magnetic separation method. The characterization methods include mass fraction and X-ray diffraction (XRD). It obtained that the average mass fraction of the Tegal Lenga Beach iron sand is $54.71 \%$. The minerals oxide contained are magnesium diiron (III) oxide ( $\mathrm{Mg} \mathrm{Fe}_{2} \mathrm{O}_{4}$ and iron iron (III) titanium aluminum magnesium vanadium manganese silicon oxide (Fe $\left.\mathrm{Fe}_{4.42} \mathrm{Fe}_{5.245} \mathrm{Ti}_{4.72} \mathrm{Al}_{0.7} \mathrm{Mg}_{0.4} \mathrm{Cr}_{0.3} \mathrm{~V}_{0.15}\right)$ ( $\left.\mathrm{Fe}_{7.82} \mathrm{Mn}_{0.114} \mathrm{Si}_{0.06}\right) \mathrm{O}_{32}$ ). The main oxide mineral compound is Magnesioferrite $\left(\mathrm{MgFe}_{2} \mathrm{O}_{4}\right)$ oxide mineral of $51.34 \%$.
\end{abstract}

Key words: Mineral oxide, Tegal Lenga Beach iron sand, X-ray diffraction (XRD)

\begin{abstract}
Penelitian penentuan kandungan mineral oksida pasir besi Pantai Tegal Lenga dengan menggunakan XRD telah dilakukan. Sampel pasir besi diambil dari lapisan atas pasir Pantai Tegal Lenga. Tiga sampel pasir diambil dari tiga tempat berbeda yang dipisahkan pada jarak 15 m satu sama lain. Proses pemisahan dilakukan dengan menggunakan metode pemisahan magnetik. Metode karakterisasi meliputi fraksi massa dan difraksi sinar-X (XRD). Diperoleh bahwa fraksi massa rata-rata pasir besi Pantai Tegal Lenga adalah 54,71\%. Mineral oksida yang terkandung adalah magnesium diiron (III) oksida ( $\mathrm{Mg} \mathrm{Fe} 2 \mathrm{O}$ ) dan besi besi (III) titanium aluminium magnesium vanadium silikon oksida mangan (Fe4.42 Fe5.245 Ti4.72 Al0.7 Mg0.4 Cr0.3 V0.15) (Fe7.82 Mn0.114SiO.06) O32). Senyawa mineral oksida utama adalah mineral oksida Magnesioferrite (MgFe2O4) yaitu 51.34\%.
\end{abstract}

Kata kunci: Mineral oxide, pasir besi Pantai Tegal Lenga, X-ray diffraction (XRD)

\section{Introduction}

Iron sand minerals contain magnetic material which is a material that can be used in the automotive industry, electronics, computers to household appliances [1]. Iron sand is also one of the main raw materials in the steel industry and heavy equipment industry [2].

Iron sand is generally a beach iron sand that is widely spread along the west coast of Sumatra, south coast of Java and Bali [3]. The long coastline of the island of Bali, which is 593 kilometres (in 2013) is the potential of the distribution of iron sand minerals. Until now there is no database on the existence of iron sand minerals on the island of Bali. This study on minerals oxide contents of the Tegal Lenga Beach iron sand is an initial research of Bali Iron Sand.

\section{Research Methods}

The iron sand minerals that have been used in this study were obtained from the sand of Tegal Lenga Beach, Buleleng Regency. The three sand samples were taken from three different places which were separated at a distance of $15 \mathrm{~m}$ one another. The equipment used includes bar magnet, sample tube, scoop, plastic bag, digital balance, aluminium foil and X-ray diffraction (XRD). The scheme of the experiment is shown in Fig. 1.

Figure 1 shows the steps of the experiment are conducted. The samples of sand from Tegal Lenga Beach are sifted, cleaned from non-sand objects and washed with running water. The cleaned sand is dried under sun shine started from 10:00 to 15:00 for two days. Subsequently, the iron sand and the noniron sand are separated by the magnetic separation method. The iron sand samples are rinsed with mineral-free water and then it is dried under sun shine started from 10:00 to 15:00 for two days. The non- 
iron sand and the dried-cleaned iron sand are weighed. Finally, the dried-cleaned iron sand were characterized by XRD.

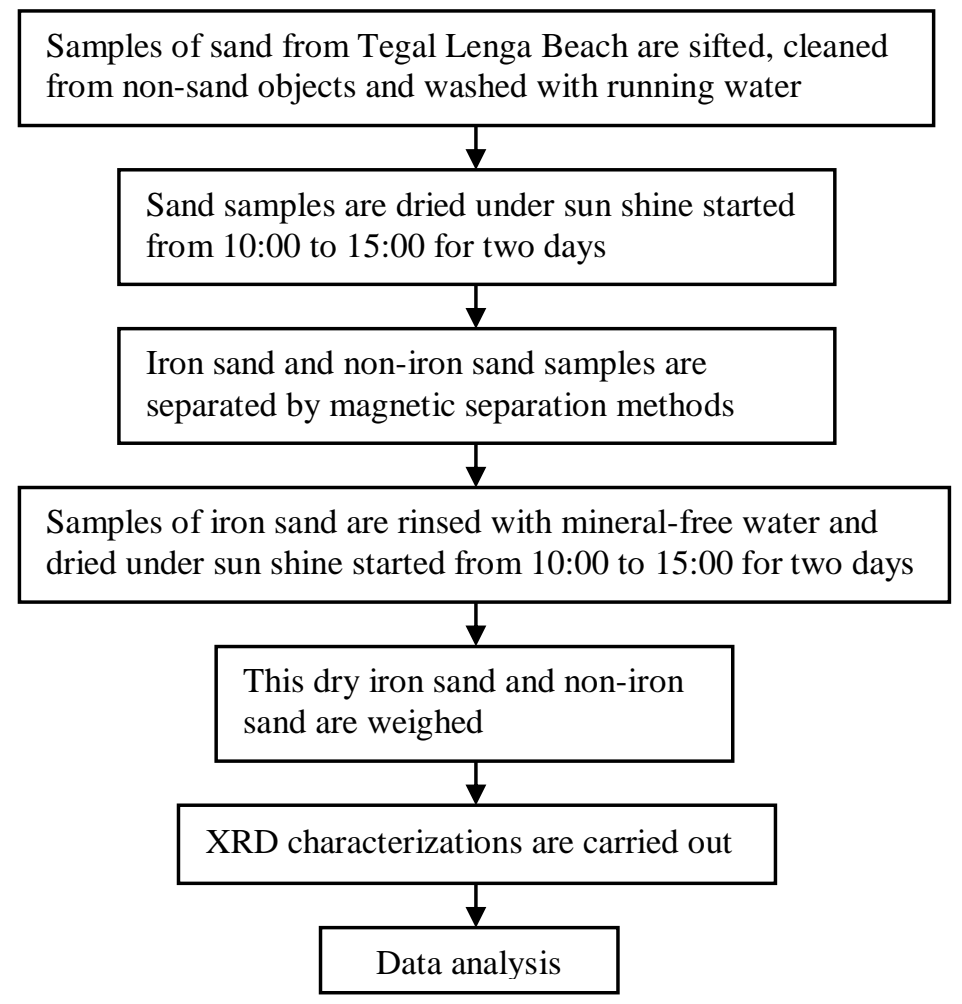

Fig. 1. The scheme of the experiment conducted.

\section{Results and Discussion}

Figure $2 \mathrm{a}$ shows the Tegal Lenga Beach sand before separated. Figure $2 \mathrm{~b}$ shows the separation process of the Tegal Lenga Beach sand by using magnetic method and Figure 2c shows the Tegal Lenga Beach iron sand obtained from the magnetic separation method.

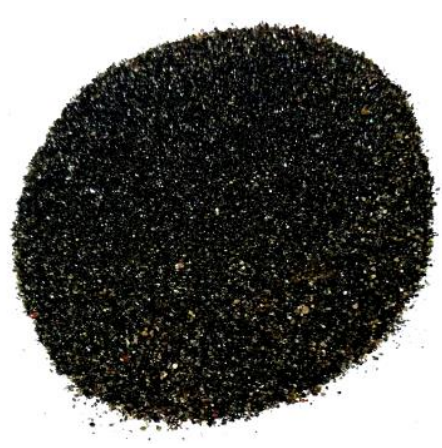

(a)

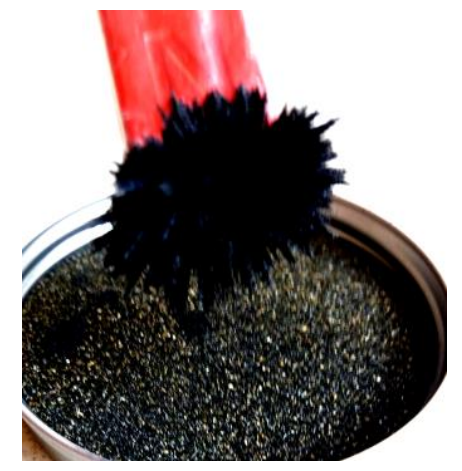

(b)

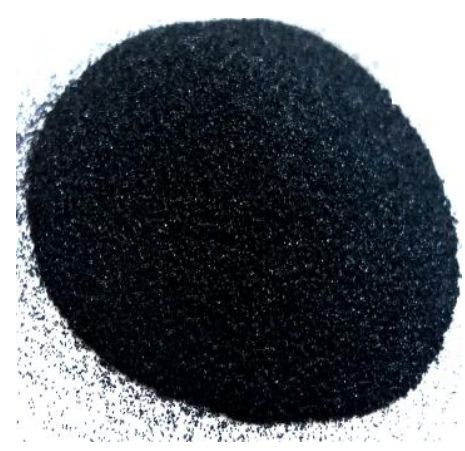

(c)

Fig. 2. (a) Tegal Lenga Beach sand before separation, (b) the separation process of the Tegal Lenga Beach sand by using magnetic method, and (c) the Tegal Lenga Beach iron sand obtained by using the magnetic separation method.

The data obtained from the separation process of iron sand and non-iron sand, which are parts of sand that stick to and not stick to the bar magnet are shown in Table 1. It shows that the percentage of the iron sand mass on each sample is almost the same. The average mass percentage of iron sand of Tegal Lenga Beach is $54.71 \%$. 
Table 1. The mass of the Tegal Lenga Beach iron sand samples.

\begin{tabular}{ccccc}
\hline No & $\begin{array}{c}\text { Mass of iron } \\
\text { sand }(\mathrm{g})\end{array}$ & $\begin{array}{c}\text { Mass of noniron } \\
\text { sand }(\mathrm{g})\end{array}$ & $\begin{array}{c}\text { Percentage of Iron } \\
\text { Sand }(\%)\end{array}$ & $\begin{array}{c}\text { Average Percentage } \\
\text { of Iron Sand }(\%)\end{array}$ \\
\hline 1 & 81.06 & 67.88 & 54.43 & \\
2 & 87.09 & 70.26 & 55.35 & 54.71 \\
3 & 72.25 & 60.65 & 54.36 & \\
\hline
\end{tabular}

The X-ray diffractogram of the three iron sand samples are shown in Fig. 3. The analyzes are shown in Table 2.

From Fig. 3 and data on Table 2 shows that the mineral oxide compounds of Sample 1 are dominated by Magnesioferrite $\left(\mathrm{MgFe}_{2} \mathrm{O}_{4}\right)$ oxide minerals with a volume fraction of $62.95 \%$. The mineral oxide compounds of Sample 2 is iron iron(III) titanium aluminum magnesium chromium vanadium(III) manganese silicon oxide $\left.\left(\mathrm{Fe}_{4.42} \mathrm{Fe}_{5.245} \mathrm{Ti}_{4.72} \mathrm{Al}_{0.7} \mathrm{Mg}_{0.4} \mathrm{Cr}_{0.3} \mathrm{~V}_{0.15}\right)\left(\mathrm{Fe}_{7.82} \mathrm{Mn}_{0.114} \mathrm{Si}_{0.06}\right) \mathrm{O}_{32}\right)$ with a volume fraction of 39.78\%. While the mineral oxide compounds of Sample 3 are also dominated by Magnesioferrite $(\mathrm{MgFe} 2 \mathrm{O} 4)$ oxide minerals with a smaller volume fraction than Sample 1 of 39.74\%. Based on this results, it concluded that the oxide mineral content of the Tegal Lenga Beach sand is dominated by iron oxide mineral.

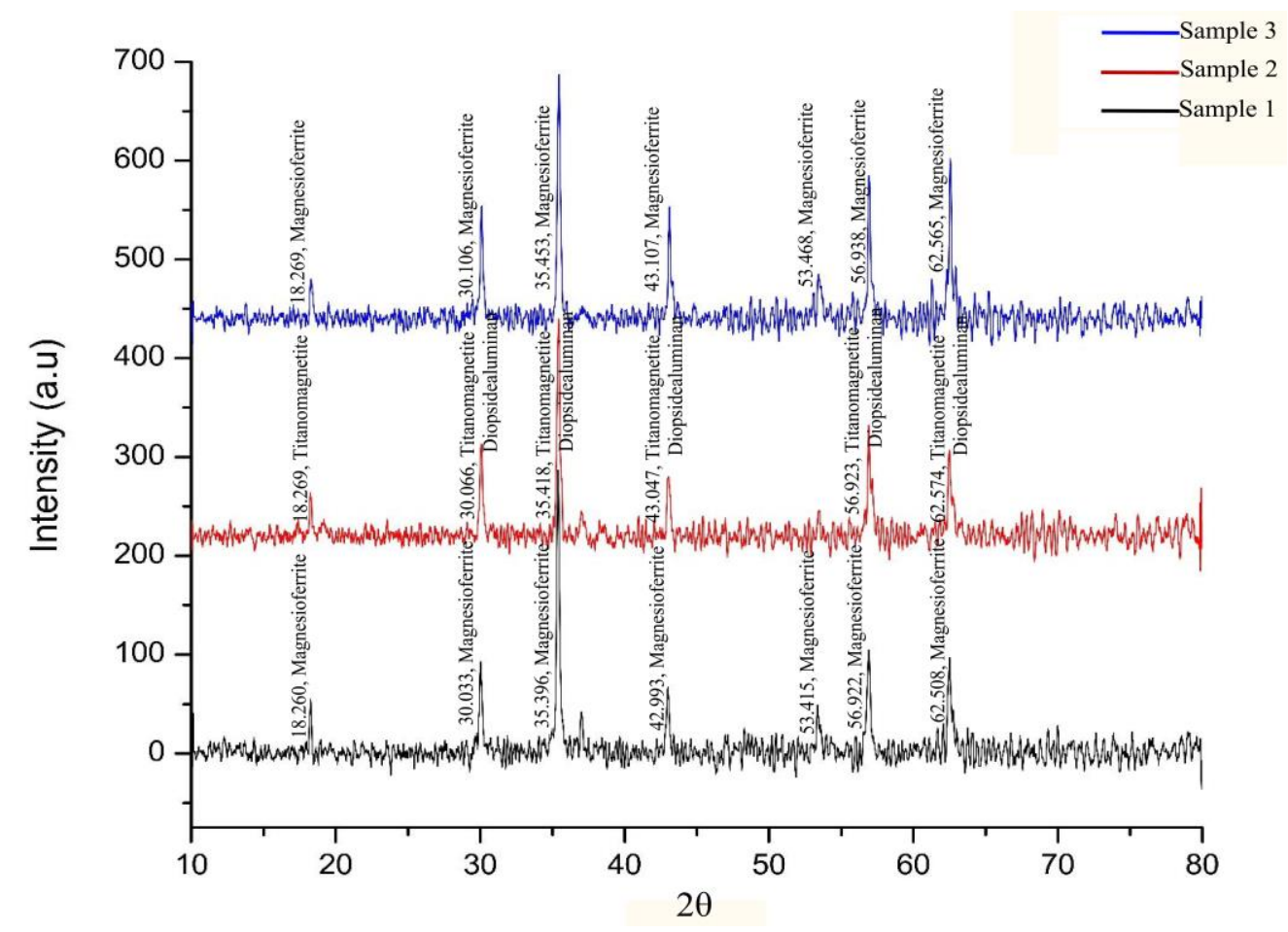

Fig. 3. The XRD pattern of the Tegal Lenga iron sand of Sample 1, 2 and 3.

Table 2. The mineral oxide compounds of Tegal Lenga iron sand.

\begin{tabular}{crllc}
\hline No. & Ref. Code & \multicolumn{1}{c}{ Compound Name } & \multicolumn{1}{c}{ Chemical Formula } & Volume Fraction (\%) \\
\hline 1 & $01-088-1943$ & Magnesium diiron(III) oxide & $\mathrm{Mg} \mathrm{Fe}_{2} \mathrm{O}_{4}$ & 62.95 \\
2 & $01-074-2034$ & $\begin{array}{l}\text { Iron iron(III) titanium } \\
\text { aluminium magnesium } \\
\text { chromium vanadium(III) }\end{array}$ & $\begin{array}{l}\left(\mathrm{Fe}_{4.42} \mathrm{Fe}_{5.245} \mathrm{Ti}_{4.72} \mathrm{Al}_{0.7}\right. \\
\left.\mathrm{Mg}_{0.4} \mathrm{Cr}_{0.3} \mathrm{~V}_{0.15}\right)\left(\mathrm{Fe}_{7.82}\right.\end{array}$ & 39.78 \\
& & $\begin{array}{l}\text { manganese silicon oxide } \\
\left.\mathrm{Mn}_{0.14} \mathrm{Si}_{0.06}\right) \mathrm{O}_{32}\end{array}$ & \\
3 & \multirow{2}{*}{$01-088-1938$} & Magnesium diiron(III) oxide & $\mathrm{Mg} \mathrm{Fe}_{2} \mathrm{O}_{4}$ & 39.74 \\
\hline
\end{tabular}




\section{Conclusion}

The determination of the oxide mineral contents of the Tegal Lenga beach iron sand by using XRD has been done. It obtained that the average mass fraction of the Tegal Lenga Beach iron sand is $54.71 \%$. The

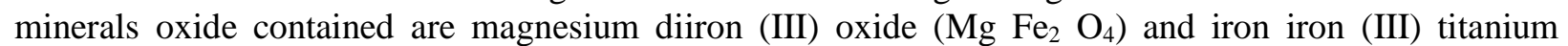
aluminum magnesium vanadium manganese silicon oxide $\left(\mathrm{Fe}_{4.42} \mathrm{Fe}_{5.245} \mathrm{Ti}_{4.72} \mathrm{Al}_{0.7} \mathrm{Mg}_{0.4} \mathrm{Cr}_{0.3} \mathrm{~V}_{0.15}\right)\left(\mathrm{Fe}_{7.82}\right.$ $\left.\mathrm{Mn}_{0.114} \mathrm{Si}_{0.06}\right) \mathrm{O}_{32}$ ) with the volume fraction of each compound are $62.95 \%, 39.78 \%$ and $39.74 \%$. The main oxide mineral compound is Magnesioferrite $\left(\mathrm{MgFe}_{2} \mathrm{O}_{4}\right)$ oxide mineral of $51.34 \%$.

\section{Acknowledgement}

We thank to Udayana University for the research budget, PUPS 2019 as well as the publication.

\section{References}

[1] Zulkarnain, 2000, Kemungkinan Pemanfaatan Pasir Besi Pesisir Pantai Aceh untuk Fabrikasi Magnet, Prosiding Seminar Nasional Bahan Magnet I, Serpong, 11 Oktober 2000, ISSN 1411-7630, pp. 59-61

[2] Yulianto, A., Bijaksana, S. dan Loeksmanto, W, Karakterisasi Magnetik dari Pasir Besi Cilacap. Jurnal Fisika, Himpunan Fisika Indonesia, Suplemen Prosiding, Hal. A5-0527, 2002.

[3] Yulianto, A., Bijaksana, S. dan Loeksmanto, W, Comparative Study on Magnetic Characterization of Iron Sand from Several Locations in Central Java.Kontribusi Fisika Indonesia, Vol. 14, No. 2, Hal. 63-66, 2003.

[4] Kementrian Energi dan Sumber Daya Mineral, Badan Geologi, Pusat Daya Geologi, Pasir Besi di Indonesia, Geologi, Ekplorasi, dan Pemanfaatannya, 2014.

[5] Bilalodin, Kajian sifat Magnetik dari Pasir Besi Pantai Logending Kabupaten Kebumen, Molekul, Vol. 5, No. 2, 2010.

[6] Peters, C. dan Thompson, R, Magnetic Identification of Selected Natural Iron Oxides and Sulphides. Journal of Magnetism and Magnetic Materials, Vol. 183, Hal. 365- 374, 1998

[7] Kementerian Riset dan Teknologi, Universitas Udayana, Rencana Induk Penelitian (RIP) Universitas Udayana 2017 - 2021, 2016. 